\title{
Practicing farmer training on happy seeder: An effort for paddy residue management in Ambala district (Haryana)
}

\section{GURU PREM, AFZAL AHMAD, VIKRAM D. SINGH AND RAMESH KUMAR}

Received : 12.07.2017; Revised : 24.08.2017; Accepted : 10.09.2017

See end of the Paper for authors' affiliation Correspondence to :

\section{GURU PREM}

Krishi Vigyan Kendra, AMBALA (HARYANA) INDIA

Email : gpgrover79@gmail. com
-ABSTRACT : Practicing farmers trainings were conducted in the then adopted village Landa in block of Barara of Ambala district in Haryana during 2012-13. During 2013-14 and 2014-15 these were conducted in village Spheda and Goli in the block of Ambala-II and Saha, respectively. The innovative farmers of the above villages were selected for conducting these demonstrations. The per cent reduction in weed population in the happy seeder sown crop over the farmer's practice was 24.49, 27.19 and 21.88, respectively during the demonstration period. The average grain yield of wheat in percentage was $9.09,8.89$ and 9.68 higher in happy seeder sown fields as compared to the conventional sown fields. In general Rs. 2920 per hectare was saved in happy seeder fields over farmer's practice for sowing of the fields. Due to reduced cost of cultivation and higher crop yield, the gross and net return was also higher in happy seeder as compared to the conventional sowing. The BCR was 3.74, 3.82 and 4.06 in happy seeder, which was higher than in conventional sowing $2.81,2.85$ and 3.01 , respectively.

- KEY WORDS : Wheat practicing farmer trainings, Happy seeder, Yield, Economics

-HOW TO CITE THIS PAPER : Prem, Guru, Ahmad, Afzal, Singh, Vikram D. and Kumar, Ramesh (2017). Practicing farmer training on happy seeder: An effort for paddy residue management in Ambala district (Haryana). Internat. J. Agric. Engg., 10(2) : 521-525, DOI: 10.15740/HAS/IJAE/10.2/ 521-525. 